\title{
Border Alert System for Fisherman using RSSI
}

\author{
G. Kanagavalli, R. Mohan Raj, R.S. Sidharth Raj
}

\begin{abstract}
Increasing strains across the ocean fringes caused extensive destruction between two countries. Anglers from any nation are being snatched for the perimeter by the service force, which is accidental to the bulk of the circumstances. Following the domain of watercraft victimization RSSI, the feasible generation of this system works, provides strong transcription path and temporary arrangement equipment for total shoppers on an identical substructure all told climate, day associate degree night on or near Earth and initiate an exhortation signal once the city district is taken closer or passed. Withal, in further organizing, the understanding of RSSI is transferred to the bone fence and thus the speed of the engine of the watercraft takes off the engine by managing the fuel supply. Later on, sentinels on the coast will profit and provide the anglers with additional profit and not travel near the district of the town.
\end{abstract}

\section{INTRODUCTION}

Route in motion can be one of the leading apps in maritime travel. Since its typical unfolding and lack of technique, the ocean path is not as simple as the road motion. For the safe path, show anglers in the state city district and reject them as achievable from the junction on these lines. The predicated prohibiting structure of the Rssi module provides helpful, valid time pontoon tracking and discovered and retaining space[1-3]. This structure tells wherever the pontoon is exclusively situated, as this structure provides property details. The real time parameter, as an instance, the right range and the region unit of latitude information accounted for drifting sentineanglers when the ship travels towards as achievable [4].

\section{EXISTING SYSTEM}

Tens of legion folks worldwide rely upon marine fishing for his or her bread and butter. Marine fishermen pay 5-7 days confounded throughout one fishing trip. Sometimes, they're going as so much as a hundred and twenty klick off from the shore in search of fish throughout these fishing visits; they're fully isolated from land as there's no economically viable manner for them to remain connected as of currently this might cause mental depression. The fishermen may additionally realize themselves in AN emergency state of affairs attributable to the natural and unreal disasters confounded they do not have the simplest way to speak with

Revised Manuscript Received on August 22, 2019.

Kanagavalli, Department of Electronics and Communication Engineering, Bharath Institute of Higher Education and Research, Chennai, Tamilnadu, India.

R. Mohan Raj, Department of Electronics and Communication Engineering, Bharath Institute of Higher Education and Research, Chennai, Tamilnadu, India.

R.S. Sidharth Raj, Department of Electronics and Communication Engineering, Bharath Institute of Higher Education and Research, Chennai, Tamilnadu, India. the land in such things. These observations came out of the survey of a couple of hundred fishermen on the south West Coast of Republic of India conducted by United States of America [5-8].

HARDWARE

- Arduino uno

- Ultrasonic sensor

- Vibration sensor

- Switch

- Voice board

- Rssi

- Motor

SOFTWARE

- Embedded c

- Arduino software

\section{WORKING}

The GPS electronic equipment can endlessly offer the signal that determines the latitude and line of longitude and indicates the position of the fishermen to them that gets scan and displayed within the liquid crystal display. a similar knowledge is distributed to the mobile of the fisher and at the same time a similar knowledge is distributed to the ocean border security. Associate in Nursing EEPROM is employed to store the info, received by GPS receiver. The hardware that interfaces with microcontroller are show $|\mathrm{LCD}|$ digital display| alphanumeric display\} display, GSM electronic equipment and GPS Receiver. GPS provides reliable positioning, navigation, and temporal arrangement services to worldwide users on an eternal basis altogether weather, day and night, anyplace on or close to the planet. All we have a tendency to needis Associate in Nursing correct clock. The latitude and longitudinal degree of the place of the boat is specified by scrutinizing the point of the satellite signal with the moment on board when the signal was transmitted. Therefore, Associate in Nursing is serially interfaced with a GSM electronic equipment AND GPS receiver by AT89c51microcontroller. [9-12].

\section{PROPOSED SYSTEM}

The projected work is allow borderline effort oceanic security framework that is generally focused round the very little scale angler WHOlive merely near the neediness line. This security arranged structure contains with transmission unit that include all learning and interface with arranged system and remote sensors and furthermore the procedure unit that survey right position of the vessel by using the restriction estimation and Receive unit screens the total strategy of transmitter and the executives through PC. The anticipated structure's motivation by reason work is talked worried by taking when fragments. This system is

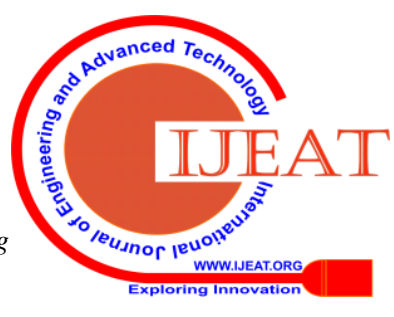


utilized to detect the territories and points of confinement of 3 stages in seashores with encourage of RSSI and also close to home to city locale shield the two level edges B1, B2 zone refined segments territory unit place away inside the overwhelming unit. On the off likelihood that a vessel crosses $\mathrm{B} 1$, the overwhelming unit can offer AN alert inside the occasion that a vessel crosses B2, motor of the barge are the transmitter sq. and furthermore the gatherer upset this can be used to transmit the data from the shoreline front screen zone and furthermore the vessel at the sea. The prepared arrangement of the projected work is includes of three levels that area unit 1st level is adrift level that demonstrates the everyday condition by and inexperienced at the beach front monitor area and also the following level is at fringe one that shows by the flag that is provides a voice alarm to the vessel from the sea-coast area and next level is near the city district two that is shown by a red shading within the city district area which is able to consequently watercraft is halted [13-18].

\section{BLOCK DIAGRAM}

\section{TRANSMITTER (BOAT)}

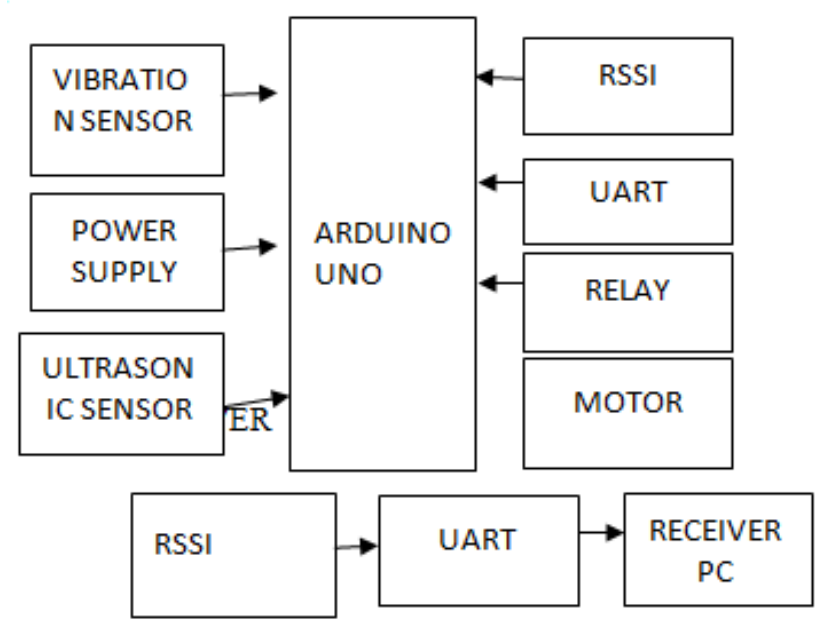

\section{METHODOLOGY}

RSSI Model and issues on paper, the vitality of a radio radiation weakens with the sq. of the space from the sign's stock. Therefore, a hub being mindful to a radio transmission should be prepared to utilize the quality of the got sign to ascertain its good ways from the transmitter. Since every one of the hubs territory unit having radios, RSSI are frequently acclimated figure ranges for restriction. forward that the transmission control Ptx, the trail misfortune model, and hence the way misfortune steady I zone unit distinguished, the beneficiary will utilize the got sign quality Prcvd to unwind for the space $\mathrm{d}$ in an exceedingly way misfortune condition like This is engaging since no additional equipment is basic and separation evaluations will even be determined while not additional overhead from correspondence that is going on in any case. [19] RSSI has bound renowned issues that got the chance to be considered: - RSSI qualities don't appear to be consistent anyway will vigorously waver, in spite of the fact that there's no development in sender and recipient. This effect are frequently neutralized by perpetual estimations and sifting through wrong qualities by applied science methods. • If institutionalization of gadget isn't been done then steady real signal quality may wind up totally different| in a few in numerous \} RSSI worth on various gadgets. Correspondingly, the specific transmission intensity of such a handset demonstrates disparities with multi-way debilitating. • Presence of hindrances together with multi-way debilitating. In such case the sign lessening on Associate in Nursing circuitous way is more than the directpath, will cause erroneously advance an all-encompassing separation than what's extremely the situation. - For an encased application, RSSI can have a reasonable a great deal of vital effect, on the grounds that the radio radiation are regularly covered with the circling environment, and in this manner the reflections can deliver a multi-way goals. The dividers and in this way the household item can fill in as hindrances for the radio radiation, anyway those region unit changeless obstructions, whose impacts got to taken consideration inside the programming. - in an exceedingly working environment like an examination lab, working environment or path, the development of people goes about as extra obstructions for the radio sign. they're versatile, and don't appear to be never-endingly blessing. in this manner the radio proliferation profile can have an uncommon structure whenever figured at daytime or at the long stretches of murkiness. Still RSSI is most well-preferred for clear area estimation algorithmic principle since: (I) No extra equipment is required. (ii) It are regularly utilized for each indoor and outside applications just with the alteration of way misfortune consistent $I$ in nuclear weight (1).

\section{APPLICATION}

- Fishermen easily identify the limit of the border [20]

\section{CONCLUSION}

The Border's scheduled document ready and followed sharply with RSSI warning mistreatment has become a coffee enterprise. What's more, the undertaking goes to give placidity on the fringes and lowers the pressure between the two countries. The most notable benefit of the RSSI system is that the environment of the development to appear in any climatic circumstances and in any meaning is the engineering of the scheduled structure. In addition, the scheduled structure can integrate a waterproof that does not incline the loop to any harm. The framework planned will not simply alarm the anglers but conjointly conveys the info to the management station and furthermore advises the relatives through the RSSI framework. On the off probability that the vessel is woolly attributable to harsh states of the ocean (or) purposeful intersection of the fringe is finished, then the info is instantly sent to the perimeter security and therefore the obligatory move is formed.

\section{REFERENCES}

1. Kongkham, D. \& Sundararajan, M. 2019, "Distributed wideband sensing method for faded dynamic spectrum access", International Journal of Innovative Technology and Exploring Engineering, vol. 8, no. 10, pp. 4309-4312.

2. Balaji, S., John Paul Praveen, A. \& Mohanraj, R. 2019, "Recognizable proof and analysis of palm print in biometric 
authentication system using bayes techniques", International Journal of Innovative Technology and Exploring Engineering, vol. 8, no. 9 Special Issue 3, pp. 1126-1129.

3. Kavitha, G., Priya, N., Velvizhi, R. \& Allin Geo, A.V. 2019, "Parallel computation in correspondence and signal processing", International Journal of Innovative Technology and Exploring Engineering, vol. 8, no. 9 Special Issue 3, pp. 1136-1139.

4. Hema, R., Sundararajan, M. \& Balaji, S. 2019, "Smartphone control robot with automatic firing gun", International Journal of Innovative Technology and Exploring Engineering, vol. 8, no. 9 Special Issue 3, pp. 625-627.

5. Kaliyamurthie, K.P., Sundar Raj, B., Velvizhi, R. \& Shanmugapriya, K. 2019, "Dual band paper substrate CPW antenna for wireless applications", International Journal of Innovative Technology and Exploring Engineering, vol. 8, no. 9 Special Issue 3, pp. 605-608.

6. Geo, A.V.A., Arunachalam, A.R., Michael, G. \& Elankavi, R. 2019 , "Evaluating architecture using compact modalities", International Journal of Innovative Technology and Exploring Engineering, vol. 8, no. 9 Special Issue 3, pp. 836-838.

7. Theivasigamani, S., Jeyapriya, D. \& Anita Davamani, K. 2019 , "Anamoly analyzing and exploring for wireless sensor networks", International Journal of Innovative Technology and Exploring Engineering, vol. 8, no. 9 Special Issue 3, pp. 1116-1118.

8. Jeyapriya, D., Theivasigamani, S., Velvizhi, R. \& Nandhini, P. 2019, "Program detection in wireless feeler networks", International Journal of Innovative Technology and Exploring Engineering, vol. 8, no. 9 Special Issue 3, pp. 1194-1195.

9. Gowri Sankaran, B., Karthik, B. \& Vijayaragavan, S.P. 2019, "Image compression utilizing wavelet transform", International Journal of Innovative Technology and Exploring Engineering, vol. 8, no. 10, pp. 4305-4308

10. Gowri Sankaran, B., Karthik, B. \& Vijayaragavan, S.P. 2019, "Weight ward change region plummeting change for square based image huffman coding", International Journal of Innovative Technology and Exploring Engineering, vol. 8, no. 10, pp. 4313-4316.

11. Hema, R., Sundararajan, M. \& Balaji, S. 2019, "Smartphone control robot with automatic firing gun", International Journal of Innovative Technology and Exploring Engineering, vol. 8, no. 9 Special Issue 3, pp. 625-627.

12. Rangaswamy, K. \& Rajabhushanam, C. 2019, "Congestion control in wireless network using TCP friendly rate control (TFRC)", International Journal of Recent Technology and Engineering, vol. 8, no. 2 Special issue 3, pp. 1598-1602.

13. Tamil Selvan, S. \& Sundararajan, M. 2019, "Performance Parameters of 3 Value 8t Cntfet Based Sram Cell Design Using H-Spice", International Journal of Recent Technology and Engineering, vol. 8, no. 2 Special issue 5, pp. 22-27.

14. Vinoth, V.V. \& Kanniga, E. 2019, "Steganographical techniques in hiding text images - system", International Journal of Recent Technology and Engineering, vol. 8, no. 2, pp. 6535-6537.

15. Saravana, S., Balaji, S., Arulselvi, S. \& John Paul Praveen, A. 2019 "Reliable power quality monitoring and protection system", International Journal of Innovative Technology and Exploring Engineering, vol. 8, no. 9 Special Issue 3, pp. 644-645

16. Sundaramoorthy, A. \& John Wiselin, M.C. 2019, "Single patch antenna with multiple feed", International Journal of Innovative Technology and Exploring Engineering, vol. 8, no. 9, pp. 1743-1747.

17. Velavan, R., Bharanidharan, S. \& Sheeba, B. 2019, "EMF pollution Causes, effects and protection", International Journal of Innovative Technology and Exploring Engineering, vol. 8, no. 9 Special Issue 3, pp. 1166-1168.

18. Veer, R.A., Arulselvi, S. \& Karthik, B. 2019, "Construction of ensemble square classification approaches in MIMO OFDM", International Journal of Engineering and Advanced Technology, vol. 8, no. 5, pp. 2039-2041.

19. Agitha, W. \& Kaliyamurthie, K.P. 2019, "Improved energy efficient in WBAN using MAC with cloud computing", International Journal of Innovative Technology and Exploring Engineering, vol. 8, no. 8, pp. 2405-2408.

20. Kastro, G.G. \& Wiselin, M.C.J. 2019, "Design and analysis of stub loaded resonator", International Journal of Recent Technology and Engineering, vol. 8, no. 1 Special Issue4, pp. 272-283.

\section{AUTHORS PROFILE}

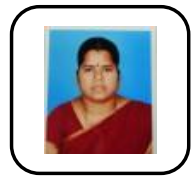

G. Kanagavalli, Assistant Professor, Department of Electronics and Communication Engineering, Bharath Institute of Higher Education and Research, Chennai, India

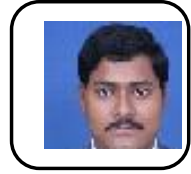

R. Mohan Raj, Assistant Professor, Department of Electronics and Communication Engineering, Bharath Institute of Higher Education and Research, Chennai, India

R.S. Sidharth Raj, Assistant Professor, Departmen of Electronics and Communication Engineering, Bharath Institute of Higher Education and Research, Chennai, India 